\title{
Erratum to: Electrochemical dissolution of metallic platinum in ionic liquids
}

\author{
Clio Deferm • Jaco Hulsegge • Claudia Möller • \\ Ben Thijs
}

Published online: 18 June 2013

(C) Springer Science+Business Media Dordrecht 2013

\begin{abstract}
The electrochemical dissolution of Pt in several ionic liquids (ILs) was studied. Different ILs were tested assessing their potential to dissolve Pt. Dissolution rate and current efficiency were evaluated. The main focus was on $\mathrm{Cl}$ containing ILs: first generation, eutectic-based ILs and second generation ILs with discrete anions. Pt dissolution only occurred in type 1 eutectic-based ILs with a max. dissolution rate of $192.2 \mathrm{~g} \mathrm{~m}^{-2} \mathrm{~h}^{-1}$ and a max. current efficiency of $99 \%$ for the $\mathrm{ZnCl}_{2}$-1-ethyl-3-methylimidazolium chloride IL, and $9.090 \mathrm{~g} \mathrm{~m}^{-2} \mathrm{~h}^{-1}$ and $96 \%$ for the 1:1 $\mathrm{ZnCl}_{2}$-choline chloride IL. The dissolution occurred through the formation of $\left[\mathrm{PtCl}_{\mathrm{x}}\right]^{\mathrm{y}-}$ complexes. To form these complexes, addition of a metal chloride was necessary. Furthermore, an IL with an electrochemical window of $1.5 \mathrm{~V}$, preferably $2.0 \mathrm{~V}$ was required to achieve $\mathrm{Pt}$ dissolution. The added metal salt needed to have a higher decomposition potential than $1.5 \mathrm{~V}$ or should be a Pt salt.
\end{abstract}

Keywords Platinum - Electrodissolution - Ionic liquids · $\mathrm{ZnCl}_{2}-\mathrm{EMIC} \cdot \mathrm{ZnCl}_{2}-\mathrm{ChCl}$

Unfortunately, there are many typo errors in the original publication of the article. The correct version is provided in this erratum.

The online version of the original article can be found under doi:10.1007/s10800-013-0541-6.

C. Deferm ( $\square)$

Department of Chemistry, K.U. Leuven, Celestijnenlaan 200 F,

Bus 2404, 3001 Leuven (Heverlee), Belgium

e-mail: deferm_clio@hotmail.com

J. Hulsegge · C. Möller · B. Thijs

Recycling and Extraction Technology (RET), Umicore

Research, Kasteelstraat 7, 2250 Olen, Belgium

\section{Introduction}

Platinum group metals (especially Pt) play a key role in modern society, as they possess a range of unique chemical and physical properties. Pt is soft, ductile and resistant to oxidation and high temperature corrosion. Due to these properties it is highly suitable in a broad range of applications. Important applications, beyond the well-known areas of chemical process catalysis and automotive emissions control, include information technology (IT), consumer electronics, a variety of medical uses and sustainable energy production such as fuel cells [1-5].

Given the need to expand almost all of these markets to meet the environmental and technological challenges of this century, the demand for Pt is expected to continuously grow [6]. However, the limited resources of Pt pose a problem. One way to ensure adequate supplies is to increase exploration and extraction of geological deposits $[5,7,8]$. Increasing the efficiencies of processes involved may offer some additional gains, but recycling efforts are vital to keep up with the demand. As a result the growing demand for pure Pt metal and its alloys makes it necessary to develop efficient and environmentally friendly recycling processes. The recycling of $\mathrm{Pt}$ is a challenging and complicated process [9-16], which in a first step requires its dissolution. Platinum is considered to be one of the "noblest" metals. Thus far, only highly corrosive reagents like, aqua regia $\left(\mathrm{HNO}_{3} / \mathrm{HCl}\right)[10,11]$ or strong oxidative reagents like piranha acid $\left(\mathrm{H}_{2} \mathrm{SO}_{4} / \mathrm{H}_{2} \mathrm{O}_{2}\right)[12,13]$ have been used for its dissolution.

Electrochemical dissolution in ionic liquids (ILs) is a possible solution to this challenge. ILs are defined as salts that melt below $100{ }^{\circ} \mathrm{C}$, typically consisting of an organic cation and a wide range of anions. These days ILs have received great interest due to their unique properties. The 
Table 1 Summary of ionic liquids (ILs)

\begin{tabular}{|c|c|c|}
\hline IL & Component(s) & Ratio $(\mathrm{mol} \%)$ \\
\hline $\mathrm{ZnCl}_{2}-\mathrm{EMIC}$ & $\begin{array}{l}\text { Zinc chloride (Technipur, Merck) }+ \text { 1-ethyl-3- } \\
\text { methylimidazolium chloride }(>98 \% \text {, Iolitec) }\end{array}$ & $1: 3$ \\
\hline EMIC & 1-Ethyl-3-methylimidazolium chloride ( $>98 \%$, Iolitec) & Pure \\
\hline $\mathrm{ZnCl}_{2}-\mathrm{ChCl}$ & $\begin{array}{l}\text { Zinc chloride (Technipur, Merck) }+ \text { choline chloride (exp } \\
\text { DAB } 10, \text { FCC, Merck) }\end{array}$ & $1: 1$ \\
\hline Ethaline (Scionix) & $\begin{array}{l}\text { Ethylene glycol + choline chloride (exp DAB 10, FCC, } \\
\text { Merck) }\end{array}$ & $2: 1$ \\
\hline Reline (Scionix) & Urea + choline chloride (exp DAB 10, FCC, Merck) & $2: 1$ \\
\hline $\mathrm{ZnCl}_{2}$-ethaline & Zinc chloride (Technipur, Merck) + ethaline (Scionix) & $1: 8.2$ \\
\hline $\mathrm{ZnCl}_{2}$-reline & Zinc chloride (Technipur, Merck) + reline $($ Scionix $)$ & 1:9.4 \\
\hline
\end{tabular}

most important properties of IL electrolytes are their extremely low volatility, a high electrochemical stability (electrochemical windows $>2 \mathrm{~V}$ ), and a relative good electric conductivity $\left(1-10 \mathrm{mS} \mathrm{cm}^{-1}\right.$ at RT) $[14,15]$.

Huang and Chen [16], from the National Chung Hsing University in Taiwan, demonstrated that electrodissolution of a large amount of Pt metal in the basic $1: 3 \mathrm{ZnCl}_{2}-1$ ethyl-3-methylimidazolium chloride ( $\mathrm{ZnCl}_{2}$-EMIC) IL at a high dissolution rate, is possible. They have also reported the recovery of pure Pt metal and the electrodeposition of Pt alloys.

The first purpose of the experiments described in this paper was to understand the system used by Huang and Chen and to develop a theory for Pt dissolution and deposition in this electrolyte.

Our purpose is to build an in-depth theory about the dissolution mechanism of this IL electrolyte system. Once this mechanism has been revealed, new and cheaper systems can be developed.

\section{Materials and methods}

\subsection{Chemicals}

Various ILs were prepared by mixing the appropriate quantities of the components in a beaker, followed by heating (1-3 h) until a clear homogeneous solution was obtained. The syntheses took place under $\mathrm{N}_{2}$ atmosphere. The ILs studied are summarized in Table 1.

\subsection{Experimental setup}

All electrochemical experiments were executed using an Autolab PGSTAT30 Potentiostat/Galvanostat controlled by Nova 1.5 software. A three-electrode electrochemical cell was used for the experiments. The electrodes used for measuring the voltammetric scans were:
- Counter electrode (CE):

- Indium tin oxide (ITO, geometric surface $2.5 \mathrm{~cm}^{2}$ )

- Glassy carbon (GC, $3 \mathrm{~mm} \varnothing$, Basi MF)

- Working electrode (WE):

- $\mathrm{GC}(3 \mathrm{~mm} \varnothing$, Basi MF)

- Pt (1.6 mm Ø, Basi MF)

- Quasi-reference electrode (RE):

- Zn wire (99.9997 \%, Alfa Aesar)

The ITO CE was fabricated by attaching (Circuitworks, Conductive Epoxy) a copper wire, as a contact, on an ITOcoated PET plate (Sigma Aldrich, $8-12 \Omega \mathrm{sq}^{-1}$ ). The epoxy loses its adhesive and conductive properties above $100{ }^{\circ} \mathrm{C}$. This puts a restrain on the operation temperature for this electrode.

All electrodes were cleaned before each experiment. The GC and Pt electrodes were polished with an aqueous slurry of $0.05 \mathrm{~mm} \mathrm{Al}$, and rinsed with deionized water and acetone. The $\mathrm{Zn}$ and ITO electrode were cleaned with deionized water and acetone before use. Prior to the measurement $\mathrm{N}_{2}$ was bubbled through the electrolyte for $30 \mathrm{~min}$.

All cyclic voltammograms (CVs) were measured in three consecutive cycles. The scan rate was always $100 \mathrm{mV} \mathrm{s}^{-1}$. For the linear sweep voltammograms (LSVs) a scan rate of $1 \mathrm{mV} \mathrm{s}^{-1}$ was used.

The chronoamperometric measurements were performed over different time lengths and with various electrodes:

- $\mathrm{CE}$ :

- Stainless steel (SS, geometric surface $3 \mathrm{~cm}^{2}$ )

- ITO (geometric surface $2.5 \mathrm{~cm}^{2}$ )

- Ti (geometric surface $1.5 \mathrm{~cm}^{2}$ )

- WE:

- Pt (geometric surface $0.3 \mathrm{~cm}^{2}$ ) 
- Quasi-RE:

- Zn wire (99.9997\%, Alfa Aesar)

- Pt wire

The ITO and Ti CEs were fabricated by attaching (Circuitworks, Conductive Epoxy) a copper wire as contact on the chosen materials. Again the operation temperature was limited due to the epoxy's loss of adhesive and conductive properties at temperatures above $100{ }^{\circ} \mathrm{C}$. The $\mathrm{Pt}$ WE consisted of four $\mathrm{Pt}$ wires coiled together forming a wire-like structure. The surface was estimated based on its geometric form. All the CE, except the ITO, were prepolished with sandpaper 800 and 1,200 grit, and all the electrodes were rinsed with deionized water and acetone before use. The electrolyte was bubbled with $\mathrm{N}_{2}$ for $30 \mathrm{~min}$ before every measurement.

A Pt wire (WE) of known weight was anodized under potential-controlled conditions. At the end of each experiment, the electrode was removed from the ionic liquid, cleaned with deionized water and acetone, dried in a furnace, and weighed again to determine the weight loss. An $\mathrm{X}$-ray fluorescence analyzer was used to examine the composition of the electrodeposits. The Pt concentration in the electrolyte after dissolution was measured with inductively coupled plasma optical emission spectrometry (ICPOES; Agilent type E730). The sample was decomposed with a mixture of $\mathrm{H}_{2} \mathrm{O}_{2}$ and $\mathrm{HNO}_{3}$ in a teflon vessel on a microwave oven. $\mathrm{H}_{2} \mathrm{O}_{2}$ and $\mathrm{HNO}_{3}$ were evaporated and the residue was dissolved in $10 \mathrm{vol} \% \mathrm{HCl}$ solution before the measurement. A calibration curve was prepared for concentration ranges of $0-50 \mathrm{mg} \mathrm{L}^{-1}$, with a QC of $25 \mathrm{mg} \mathrm{L}^{-1}$. Scandium was used as internal standard.

Since all the ILs were miscible in water, the residual ionic liquid on the electrodes was removed easily by rinsing with deionized water following each experiment.

\section{Results and discussion}

\subsection{Synthesis of ILs}

The used ILs and their main properties are summarized in Table 2. The water content is extremely important due to its significant influence on a number of properties like the electrochemical window (EW) [17], melting temperature $\left(\mathrm{T}_{\mathrm{m}}\right)$ and conductivity. Volumetric Karl Fischer titration (Metrohmv Titrator 836 Titrado; Tiamo 2.0 software) was used to determine the water content.

During the synthesis of $\mathrm{ZnCl}_{2}$-ethaline and $\mathrm{ZnCl}_{2}-$ reline ILs vapor emerged from the liquids indicating an evaporation process. The dissolved $\mathrm{ZnCl}_{2}$ destroyed the hydrogen-bonded anion complex of ethaline by complexing with a $\mathrm{Cl}^{-}$anion. The hydrogen bonds were broken and ethylene glycol was present as a neutral molecule. A new IL was formed with Choline ${ }^{+}$, $\left[2 \mathrm{CholineCl}^{+}\right.$cations and $\mathrm{ZnCl}_{3}{ }^{-}, \mathrm{Zn}_{2} \mathrm{Cl}_{5}{ }^{-}, \mathrm{Zn}_{3} \mathrm{Cl}_{7}{ }^{-}$anions, in which ethylene glycol was dissolved [18-20]. This resulted in a solution consisting of two ILs: ethaline and an IL in which ethylene glycol was dissolved. During the synthesis the evaporation of ethylene glycol and water was seen at elevated temperatures (both ethylene glycol and water have a boiling point around $100{ }^{\circ} \mathrm{C}$ at $760 \mathrm{mmHg}$ [21]).

The same principle was valid for the $\mathrm{ZnCl}_{2}$-reline IL synthesis. The hydrogen bonds were broken by $\mathrm{ZnCl}_{2}$ and urea was present as a neutral molecule. An IL was formed with Choline ${ }^{+}$, $[2 \mathrm{CholineCl}]^{+}$cations and $\mathrm{ZnCl}_{3}{ }^{-}$anions in which urea was dissolved [18]. The only difference with the ethylene glycol system was that during the synthesis no evaporation occurred since urea melts and decomposes at $135{ }^{\circ} \mathrm{C}$.

\section{$3.21: 3 \mathrm{ZnCl}_{2}-\mathrm{EMIC}$}

\subsubsection{Electrochemical analyses}

In order to understand the electrochemical behavior of the $\mathrm{ZnCl}_{2}$-EMIC IL, voltammograms were recorded with and without Pt in the system. The first measurements performed in the potential range from -3 to $+3 \mathrm{~V}$ showed unstable results and the measurement could not be repeated. After a couple of experiments it was found that the Zn RE was covered by a black layer after every experiment, insulating the RE. It was observed that this layer only appeared during the cathodic polarization of the WE at potentials below $\pm 1.25 \mathrm{~V}$. To solve this problem, voltammograms were measured from anodic to cathodic side and only to potentials of max. $-1.0 /-1.25 \mathrm{~V}$.

Figure 1 shows $\mathrm{CVs}$ of the $\mathrm{ZnCl}_{2}-\mathrm{EMIC}$ IL on a $\mathrm{GC}$ and $\mathrm{Pt} \mathrm{WE}$, recorded according to the above described method, with a scan rate of $100 \mathrm{mV} \mathrm{s}^{-1}$ at $120^{\circ} \mathrm{C}$. The potential limits for this IL correspond to the cathodic reduction of $\mathrm{EMI}^{+}$at $-0.5 \mathrm{~V}$ (peak $\mathrm{VI}$ ), and the anodic oxidation of $\mathrm{Cl}^{-}$at $2.4 \mathrm{~V}$ (peak II), resulting in an EW of approximately $2.9 \mathrm{~V}$. This is in good agreement with the determined $3 \mathrm{~V}$ by Hsiu et al. [22] and Schubert et al. [23].

A comparison between both CVs shows three additional peaks on the Pt WE. Only one anodic peak indicating a $\mathrm{Pt}$ oxidation is observed around $2.25 \mathrm{~V}$ (peak I). No peak in the same potential range is observed at the GC WE. This behavior suggests that the electrochemical oxidation of $\mathrm{Pt}$ metal is a one-step reaction. On the cathodic scan, there are two cathodic peaks at $1.2 \mathrm{~V}$ (peak III) and $1.0 \mathrm{~V}$ (peak IV), likely referring to a $\mathrm{Pt}$ reduction. These findings are in good agreement with the proposed mechanism of Huang and Chen [16]. They claim that at temperatures over $80^{\circ} \mathrm{C}$ Pt dissolves as a $\left[\mathrm{PtCl}_{6}\right]^{2-}$ complex and that the reduction 
Table 2 Selected properties of the investigated ILs

\begin{tabular}{lllll}
\hline $\mathrm{IL}$ & $\begin{array}{l}\text { Ratio } \\
(\mathrm{mol} \%)\end{array}$ & $\begin{array}{l}\mathrm{T} \text { syn. } \\
\left({ }^{\circ} \mathrm{C}\right)\end{array}$ & $\begin{array}{l}\mathrm{T}_{\mathrm{m}} \\
\left({ }^{\circ} \mathrm{C}\right)\end{array}$ & $\begin{array}{l}\text { Water } \\
\text { content } \\
(\text { vol\%) }\end{array}$ \\
\hline $\mathrm{ZnCl}_{2}$-EMIC & $1: 3$ & 90 & 80 & 0.69 \\
EMIC & - & - & 80 & 1.64 \\
Ethaline & - & - & $\mathrm{RT}$ & 2.13 \\
Reline & - & - & $\mathrm{RT}$ & 1.05 \\
$\mathrm{ZnCl}_{2}$-ethaline & $1: 8.2$ & 120 & $\mathrm{RT}$ & 3.24 \\
$\mathrm{ZnCl}_{2}$-reline & $1: 9.4$ & 120 & $\mathrm{RT}$ & 0.59 \\
$\mathrm{ZnCl}_{2}-\mathrm{ChCl}$ & $1: 1$ & 160 & 80 & 0.33 \\
\hline
\end{tabular}

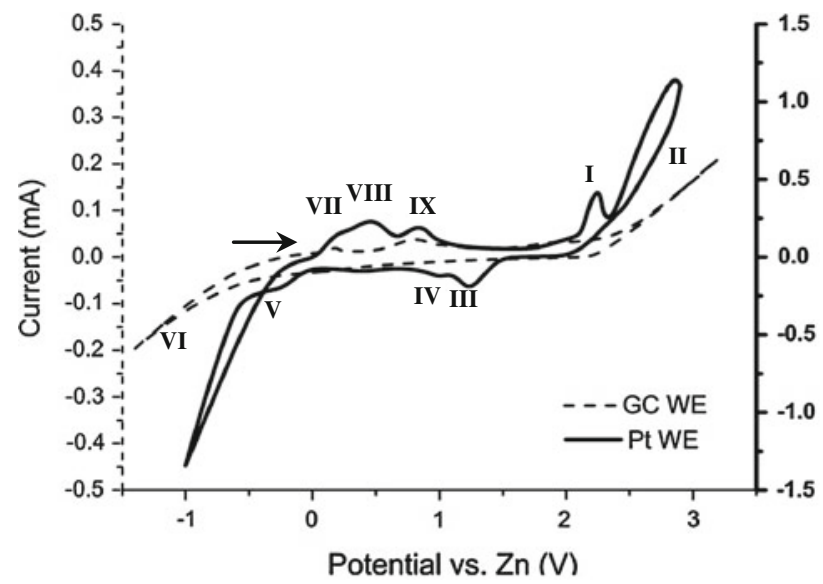

Fig. $1 \mathrm{CVs}$ of the 1:3 $\mathrm{ZnCl}_{2}$-EMIC IL recorded on a GC (dashed line) and $\mathrm{Pt}$ (solid line) WE with a scan rate of $100 \mathrm{mV} \mathrm{s}^{-1}$ at $120^{\circ} \mathrm{C}$ (ITO CE dashed line, GC CE solid line) with three coinciding cycles

follows a two-step mechanism from $\mathrm{Pt}^{4+}$ to $\mathrm{Pt}^{2+}$ followed by the reduction to metallic Pt. Two additional anodic peaks (peak VIII and IX) appear in both CVs. These peaks can be assigned to the oxidation of degradation products formed during the cathodic cycle. A summary of the assigned peaks and assumed reactions is given in Table 3 .

The LSVs of the anodic polarization were measured to take a closer look into the dissolution of Pt metal. Figure 2 shows the LSVs of the 1:3 $\mathrm{ZnCl}_{2}$-EMIC IL recorded on a $\mathrm{GC}$ and $\mathrm{Pt} \mathrm{WE}$ with a scan rate of $1 \mathrm{mV} \mathrm{s}^{-1}$ at $120^{\circ} \mathrm{C}$.

From the previous proposed reaction mechanism it can be concluded that Pt oxidation was characterised by a peak starting around $2.0 \mathrm{~V}$. Chronoamperometric measurements were performed on a potential above and below $2.0 \mathrm{~V}$ to confirm that this reaction is indeed the dissolution of Pt.

\subsubsection{Chronoamperometric anodic dissolution of Pt}

Based on the preceding voltammograms (Figs. 1, 2), we assumed that $\mathrm{Pt}$ dissolves at potentials higher than $\pm 2 \mathrm{~V}$. The release of $\mathrm{Cl}_{2}$ gas around $2.4 \mathrm{~V}$ is an indication for the

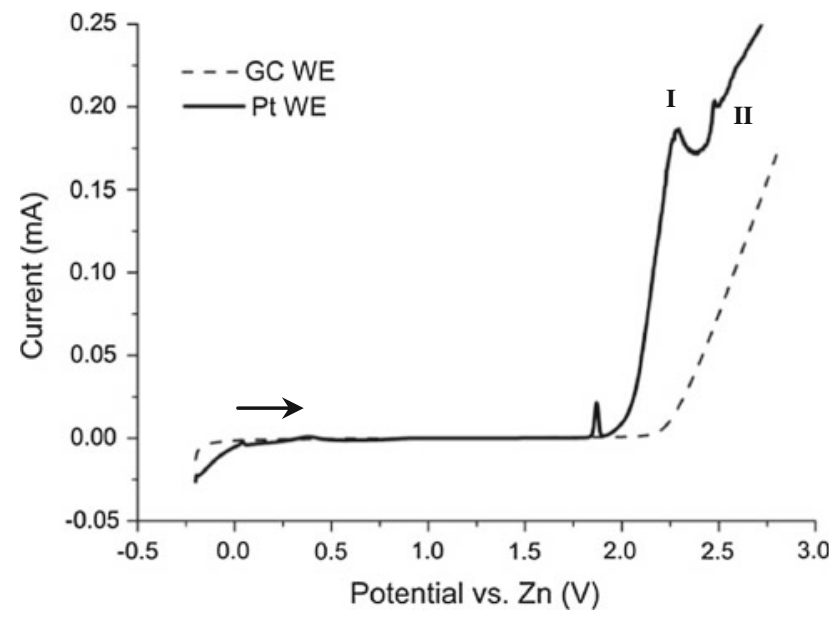

Fig. 2 LSVs of the 1:3 $\mathrm{ZnCl}_{2}$-EMIC IL recorded on a GC (dashed line) and $\mathrm{Pt}$ (solid line) WE with a scan rate of $1 \mathrm{mV} \mathrm{s}^{-1}$ at $120{ }^{\circ} \mathrm{C}$ (ITO CE dashed line, GC CE solid line)

Table 3 Summary assigned peaks and assumed reactions

\begin{tabular}{ll}
\hline Peak & Assumed reactions \\
\hline I & Formation Pt complexes \\
& $\mathrm{Pt}(\mathrm{s})+\mathrm{xCl}^{-} \rightarrow\left[\mathrm{PtCl}_{\mathrm{x}}\right]^{\mathrm{y}-}+\mathrm{ye}^{-}$ \\
$\mathrm{II}$ & $2 \mathrm{Cl}^{-} \rightarrow \mathrm{Cl}_{2}(\mathrm{~g})+2 \mathrm{e}^{-}$ \\
$\mathrm{III}+\mathrm{IV}$ & $\mathrm{Two}-\mathrm{step}$ reduction formed Pt complexes \\
& {$\left[\mathrm{PtCl}_{\mathrm{x}}\right]^{\mathrm{y}-} \rightarrow[\mathrm{PtCl}]^{\mathrm{v}-} \rightarrow \mathrm{Pt}(\mathrm{s})$} \\
$\mathrm{V}+\mathrm{VII}$ & $\mathrm{Zn}^{2+}+2 \mathrm{e}^{-} \leftrightarrows \mathrm{Zn}(\mathrm{s})$ \\
$\mathrm{VI}$ & $\mathrm{EMI}^{+}+\mathrm{e}^{-} \rightarrow \mathrm{EMI}$ \\
$\mathrm{VIII}+\mathrm{IX}$ & $\mathrm{Oxidizing} \mathrm{degradation} \mathrm{products} \mathrm{of} \mathrm{EMI}$ \\
\hline
\end{tabular}

decomposition of the electrolyte and must be avoided. This implies that the applied potential to dissolve Pt must be chosen above 2, and below $2.4 \mathrm{~V}$. This is confirmed by chronoamperometric measurements below $2.0 \mathrm{~V}$ where no dissolution of Pt could be observed.

Figure 3 shows the current/time transients of the chronoamperometric anodic dissolution of a Pt electrode in the $\mathrm{ZnCl}_{2}$-EMIC IL. A potential of $2.1 \mathrm{~V}$ is applied for $8 \mathrm{~h}$. Preparatory conditioning of the electrolyte was done by applying $2.1 \mathrm{~V}$ for $50 \mathrm{~min}$. During this time, Pt ions were brought into solution and a $\mathrm{Zn}-\mathrm{Pt}$ alloy was deposited at the cathode. As shown in Fig. 3, the current increases quickly at an early stage (first 200 s) followed by a steady decline due to the decrease in size of the WE. An average current of approximately $0.0035 \mathrm{~A}$ was reached during the experiment giving a current density $(\mathrm{J})$ of $116.67 \mathrm{~A} \mathrm{~m}^{-2}$. A weight loss of $0.0492 \mathrm{~g}$ occurred, leading to a dissolution rate of $192.2 \mathrm{~g} \mathrm{~m}^{-2} \mathrm{~h}^{-1}\left(0.985 \mathrm{~mol} \mathrm{~m}^{-2} \mathrm{~h}^{-1}\right)$. The current efficiency $(\eta)$ for the dissolution was calculated to be $99 \%$, assuming a $\mathrm{Pt}^{4+}$ valence. This high dissolution efficiency and the absence of gas formation at the anode 
indicated that no $\mathrm{Cl}_{2}$ was produced during the experiment and thus no decomposition of the electrolyte occurred. Afterwards a Pt concentration of $39 \mathrm{ppm}$ was measured in solution by ICP-OES, and a Pt-Zn (4:96 \%) deposition was detected at the cathode. The $\mathrm{Zn}$ deposition can be avoided by adding $\mathrm{Pt}$ salt to the starting electrolyte. Without the addition of a $\mathrm{Pt}$ salt $\mathrm{Zn}$ will always be co-deposited due to the extremely low Pt concentrations in the electrolyte.

The experiment confirmed that the basic $1: 3 \mathrm{ZnCl}_{2}-$ EMIC IL is indeed an excellent medium for the electrodissolution of large amounts of Pt metal at a high dissolution rate. The drawback however is that it is a quite expensive system. To overcome this problem, cheaper systems were investigated.

1:3 $\mathrm{ZnCl}_{2}$-EMIC belongs to the eutectic-based ILs, and more specific to type 1 . ILs have been classified by their anionic species into so called first and second generation ILs. The first generation ILs have complex anions formed between a Lewis basic anion and a Lewis acid metal salt or a Brønsted acid hydrogen bond donor. These are, in effect, eutectic mixtures of the two components and are therefore called eutectic-based ILs. Second generation ILs have discrete anions. The eutectic based systems can be expressed in terms of the general formula $\mathrm{Cat}^{+} \mathrm{X}^{-} \cdot \mathrm{zY}$, where $\mathrm{Cat}^{+}$is basically any ammonium, phosphonium or sulfonium cation, and $\mathrm{X}^{-}$is generally a halide ion (usually $\mathrm{Cl}^{-}$). They are based on an equilibrium set up between $\mathrm{X}^{-}$ and a Lewis or Brønsted acid Y, $\mathrm{z}$ refers to the number of $\mathrm{Y}$ molecules which complex $\mathrm{X}^{-}$. The ILs described can be subdivided into three types depending on the nature of the complexing agent used [24].

- Type 1: $\mathrm{Y}=\mathrm{MCl}_{\mathrm{x}}, \mathrm{M}=\mathrm{Zn}, \mathrm{Sn}, \mathrm{Fe}, \mathrm{Al}, \mathrm{Ga}, \mathrm{In}$

- $\quad$ Type 2: $\mathrm{Y}=\mathrm{MCl}_{\mathrm{x}} \cdot \mathrm{yH}_{2} \mathrm{O}, \mathrm{M}=\mathrm{Cr}, \mathrm{Co}, \mathrm{Cu}, \mathrm{Ni}, \mathrm{Fe}$

- $\quad$ Type 3: $\mathrm{Y}=\mathrm{RZ}, \mathrm{Z}=\mathrm{CONH}_{2}, \mathrm{COOH}, \mathrm{OH}$

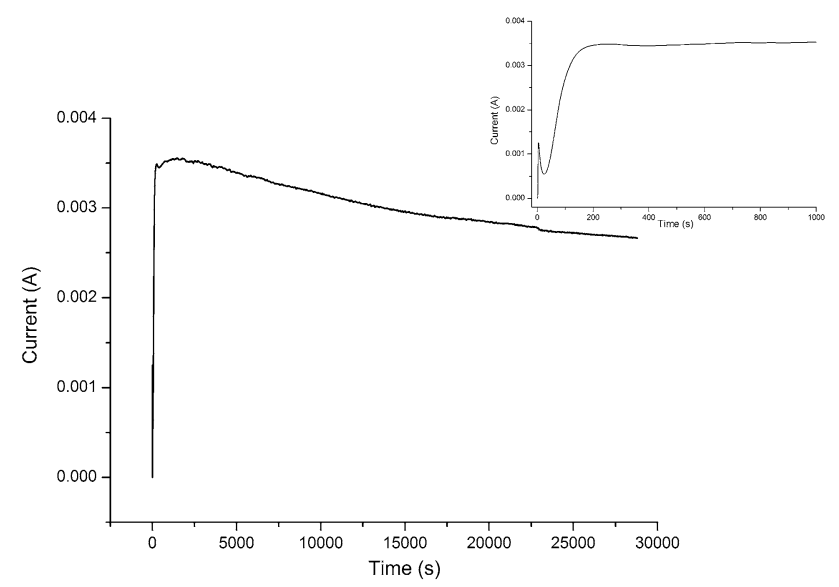

Fig. 3 Current/time transient at $\mathrm{E}=2.1 \mathrm{~V}$ in $1: 3 \mathrm{ZnCl}_{2}-\mathrm{EMIC}$ IL at $120{ }^{\circ} \mathrm{C}$ with a Pt WE (SS CE). Upper inset magnification of the current/time transients in the $0-1,000 \mathrm{~s}$ range
To make Pt dissolution industrial feasible, less expensive systems were evaluated. In order to dissolve Pt metal as a $\left[\mathrm{PtCl}_{\mathrm{x}}\right]^{\mathrm{y}-}$ complex, only $\mathrm{Cl}^{-}$anion containing ILs were chosen. Tests were performed to assess the dissolution of Pt and to develop a solid theory regarding the dissolution potential of different electrolyte types.

\subsection{Alternative electrolyte systems}

A summary of the electrolytes tested, and their potential to dissolve $\mathrm{Pt}$, is given in Table 4. All electrolytes were analyzed by cyclic and linear sweep voltammetry experiments.

Assessment of the first generation type 3 (reline, ethaline), showed that they are not able to dissolve Pt. The main difference between the $\mathrm{ZnCl}_{2}$-EMIC and the so far tested ILs, is the lack of $\mathrm{ZnCl}_{2}$ in the latter system. The incapability of Pt dissolution in EMIC, a second generation IL, proves that a metal chloride has an important role in the dissolution of Pt. Therefore $\mathrm{ZnCl}_{2}$ was added to the ethaline and reline.

However, the addition of $\mathrm{ZnCl}_{2}(0.5 \mathrm{M})$ to the systems did not change the outcome. The conclusion could be that the addition of $\mathrm{ZnCl}_{2}(0.5 \mathrm{M})$, partly destroyed the hydrogen-bonded anion complex forming a new IL with Choline ${ }^{+}$, [2CholineCl $]^{+}$cations and $\mathrm{ZnCl}_{3}{ }^{-}, \mathrm{Zn}_{2} \mathrm{Cl}_{5}{ }^{-}$, $\mathrm{Zn}_{3} \mathrm{Cl}_{7}{ }^{-}$anions in which urea or ethylene glycol was dissolved [18]. Instead of the $\mathrm{ZnCl}_{2}$-ethaline/ $\mathrm{ZnCl}_{2}$-reline IL, most probably a solution consisting of an IL containing ethaline or reline and an IL with Choline ${ }^{+}$cations and $\mathrm{ZnCl}^{-}$anions was produced in which ethylene glycol or urea was dissolved.

The type 2 eutectic based ILs were not tested. These ILs contain hydratation water. Water normally limits the EW but the role of the hydratation water molecules is still largely unknown. The authors [25-27] claim that hydratation water does not act in the same way as bulk water and that the EW is rather limited by the metallic species reduction than water-related reduction processes. However, it is the chromium system which has been published so far.

Following these results a $\mathrm{ZnCl}_{2}-\mathrm{ChCl} \mathrm{IL}$ was tested, showing positive results regarding the dissolution of $\mathrm{Pt}$.

Table 4 Alternative electrolytes

\begin{tabular}{llllll}
\hline $\mathrm{IL}$ & EW $(\mathrm{V})$ & $\mathrm{T}\left({ }^{\circ} \mathrm{C}\right)$ & Pt diss. & $\mathrm{J}\left(\mathrm{A} \mathrm{m}^{-2}\right)$ & $\begin{array}{l}\text { Max. } \eta \\
(\%)\end{array}$ \\
\hline EMIC & 2.1 & 100 & No & - & - \\
Ethaline & 1.9 & 100 & No & - & - \\
Reline & 2.0 & 100 & No & - & - \\
$\mathrm{ZnCl}_{2}$-ethaline & 2.2 & 100 & No & - & - \\
$\mathrm{ZnCl}_{2}$-reline & 2.2 & 100 & No & - & - \\
$\mathrm{ZnCl}_{2}-\mathrm{ChCl}$ & 2.9 & 100 & Yes & 5.5 & 96 \\
\hline
\end{tabular}




\subsection{1:1 $\mathrm{ZnCl}_{2}-\mathrm{ChCl} \mathrm{IL}$}

The 1:1 $\mathrm{ZnCl}_{2}$-choline chloride $\left(\mathrm{ZnCl}_{2}-\mathrm{ChCl}\right) \mathrm{IL}$ is a type 1 eutectic-based IL like 1:3 $\mathrm{ZnCl}_{2}$-EMIC but less expensive. Due to the positive Pt dissolution assessment, a full analysis of this system was made.

\subsubsection{Electrochemical analysis}

Figure 4 shows the $\mathrm{CVs}$ of the $1: 1 \mathrm{ZnCl}_{2}-\mathrm{ChCl} \mathrm{IL}$ recorded on a GC and Pt WE with a scan rate of $100 \mathrm{mV} \mathrm{s}^{-1}$ at $100{ }^{\circ} \mathrm{C}$. The potential limits for this IL correspond to the cathodic reduction of $\mathrm{Zn}$ at $-0.1 \mathrm{~V}$ (peak $\mathrm{V}$ ), and anodic oxidation of $\mathrm{Cl}^{-}$at $2.1 \mathrm{~V}$ (peak II), giving an EW of approximately $2.2 \mathrm{~V}$. This is in good agreement with the determined $2 \mathrm{~V}$ by Abbott et al. [28].

As shown in Fig. 4, three additional peaks arise in the CV recorded with the Pt WE compared to the one recorded with the GC WE. Only one anodic peak, corresponding to Pt oxidation, is observed at $2.3 \mathrm{~V}$ (peak I). Again no peak is observed at the same voltage on the GC WE. This behavior suggests that the electrochemical oxidation of $\mathrm{Pt}$ metal is a one-step reaction as already concluded previously. On the cathodic scan, there are two peaks around $1.0 \mathrm{~V}$ (peak III) and $0.55 \mathrm{~V}$ (peak IV), corresponding to a Pt reduction. Two additional anodic peaks (peak VII and VIII) appear in both CVs. These peaks were due to the oxidation of degradation products formed during the cathodic cycle. The assigned peaks and assumed reactions are presented in Table 5.

The LSVs of the anodic polarization recorded on a GC and $\mathrm{Pt}$ WE with a scan rate of $1 \mathrm{mV} \mathrm{s}^{-1}$ at $100{ }^{\circ} \mathrm{C}$ are shown in Fig. 5.

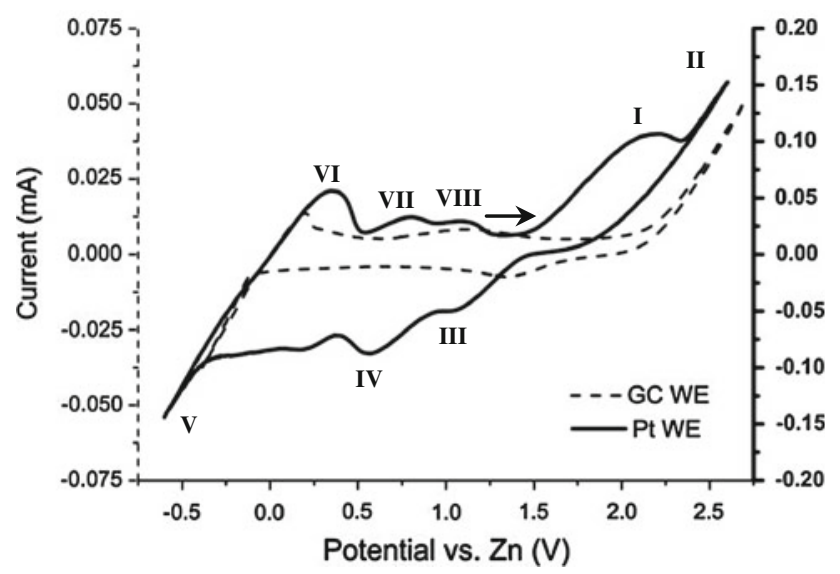

Fig. $4 \mathrm{CVs}$ of the $1: 1 \mathrm{ZnCl}_{2}-\mathrm{ChCl} \mathrm{IL}$ recorded on a $\mathrm{GC}$ (dashed line) and $\mathrm{Pt}$ (solid line) WE with a scan rate of $100 \mathrm{mV} \mathrm{s}^{-1}$ at $100{ }^{\circ} \mathrm{C}$ (ITO $\mathrm{CE}$ dashed line, GC CE solid line) with three coinciding cycles

\subsubsection{Chronoamperometric anodic dissolution of Pt}

Based on the preceding voltammograms (Figs. 4, 5), it is known that $\mathrm{Pt}$ dissolves at voltages over 1.7 V. The release of $\mathrm{Cl}_{2}$ gas around $2.1 \mathrm{~V}$ must be avoided. Dissolution experiments were conducted with a chronoamperometric setup on Pt WEs at potentials between 1.7 and $2.1 \mathrm{~V}$.

Figure 6 shows the current/time transients of one of these dissolutions in the $1: 1 \mathrm{ZnCl}_{2}-\mathrm{ChCl} \mathrm{IL}$. A potential of $2.1 \mathrm{~V}$ is applied for $6 \mathrm{~h}$. Pt ions were previously brought into solution by the same conditioning experiment already performed in the $\mathrm{ZnCl}_{2}$-EMIC IL. An ITO CE was chosen instead of a SS CE, due to the fact that the SS was etched in the $1: 1 \mathrm{ZnCl}_{2}-\mathrm{ChCl} \mathrm{IL}$, introducing $\mathrm{Fe}$ ions into the electrolyte.

During the chronoamperometric experiment, an average current of approximately $2.7 \mathrm{E}-4 \mathrm{~A}$ was reached, resembling a current density of $9 \mathrm{~A} \mathrm{~m}^{-2}$. A weight loss of $0.0005 \mathrm{~g}$ occurred, giving a dissolution rate of $2.6 \mathrm{~g} \mathrm{~m}^{-2} \mathrm{~h}^{-1}\left(0.013 \mathrm{~mol} \mathrm{~m}^{-2} \mathrm{~h}^{-1}\right)$ and a dissolution efficiency of $15 \%$. This dissolution efficiency was calculated assuming that the $\mathrm{Pt}$ dissolved as $\mathrm{Pt}^{4+}$. During the experiment $\mathrm{Cl}_{2}$ gas release was observed at the WE, explaining the low dissolution efficiency. Following the experiment, Pt was detected at the cathode in the form of dendrites.

To increase the dissolution efficiency a lower potential $(2.0 \mathrm{~V})$ was applied to avoid $\mathrm{Cl}_{2}$ gas release. The experiment was repeated with a Ti CE for 2 h 45 min (Fig. 7). $\mathrm{An}$ average current of approximately $1.66 \mathrm{E}-4 \mathrm{~A}$ was reached, resembling a current density of $5.5 \mathrm{~A} \mathrm{~m}^{-2}$. A weight loss of $0.0008 \mathrm{~g}$ occurred, giving a dissolution rate of $9.090 \mathrm{~g} \mathrm{~m}^{-2} \mathrm{~h}^{-1}\left(0.0047 \mathrm{~mol} \mathrm{~m}^{-2} \mathrm{~h}^{-1}\right)$. A dissolution efficiency of $96 \%$ was calculated. This very high dissolution efficiency was an indication that $\mathrm{Cl}_{2}$ gas release was avoided at the chosen potential.

Due to a small CE surface, a Zn layer with minor traces of $\mathrm{Pt}$ was produced at the Ti cathode and Pt powder in the electrolyte. Both confirmed by energy-dispersive X-ray spectroscopy (EDS) on the cathode (Fig. 8) and the filtered powder (Whatmann, Grade 589/2).

Table 5 Summary assigned peaks and assumed reactions

\begin{tabular}{ll}
\hline Peak & Assumed reactions \\
\hline I & Formation Pt complexes \\
& $\mathrm{Pt}(\mathrm{s}) \rightarrow\left[\mathrm{PtCl}_{\mathrm{z}}\right]^{\mathrm{v}-}$ \\
$\mathrm{II}$ & $2 \mathrm{Cl}^{-} \rightarrow \mathrm{Cl}_{2}(\mathrm{~g})+2 \mathrm{e}^{-}$ \\
$\mathrm{III}+\mathrm{IV}$ & $\mathrm{Two}^{-} \mathrm{step}$ reduction formed Pt complexes \\
& {$\left[\mathrm{PtCl}_{\mathrm{x}}\right]^{\mathrm{y}-} \rightarrow\left[\mathrm{PtCl}_{\mathrm{z}}\right]^{\mathrm{v}-} \rightarrow \mathrm{Pt}(\mathrm{s})$} \\
$\mathrm{V}+\mathrm{VI}$ & $\mathrm{Zn}^{2+}+2 \mathrm{e}^{-} \rightleftarrows \mathrm{Zn}(\mathrm{s})$ \\
$\mathrm{VII}+\mathrm{VIII}$ & Degradation products of choline \\
\hline
\end{tabular}




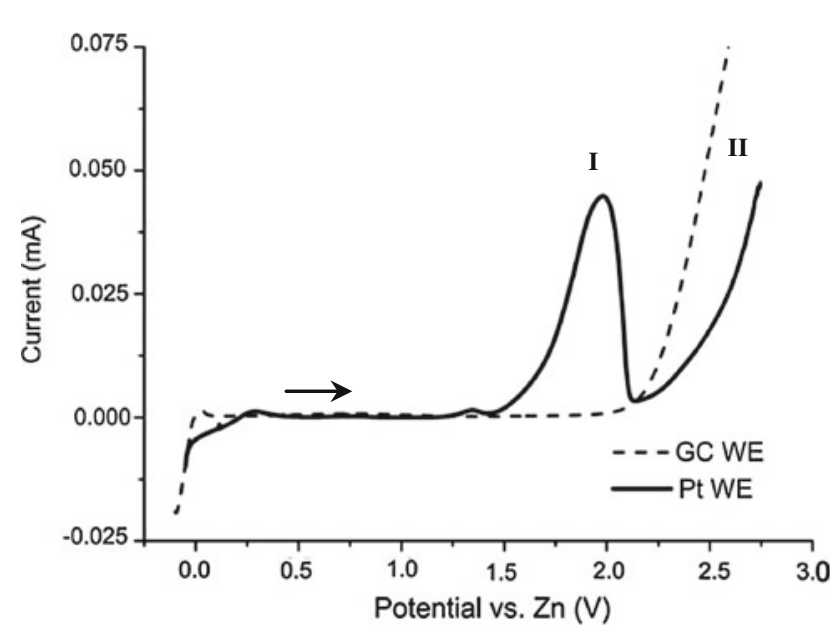

Fig. $5 \mathrm{LSVs}$ of the 1:1 $\mathrm{ZnCl}_{2}-\mathrm{ChCl} \mathrm{IL}$ recorded on a $\mathrm{GC}$ (dashed line) and $\mathrm{Pt}$ (solid line) WE with a scan rate of $1 \mathrm{mV} \mathrm{s}^{-1}$ at $100{ }^{\circ} \mathrm{C}$ (ITO CE)

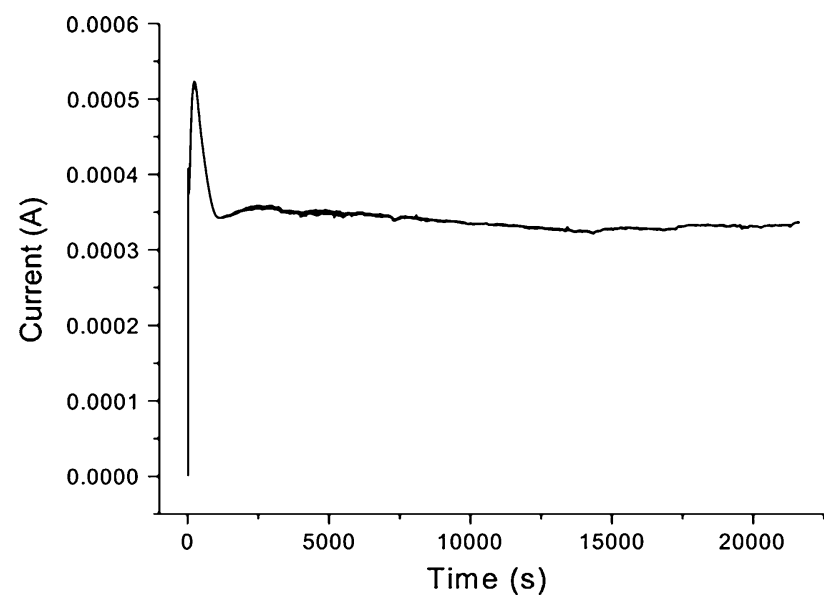

Fig. 6 Current/time transient from the chronoamperometric experiment at $\mathrm{E}=2.1 \mathrm{~V}$ for the $\mathrm{Pt}$ anodic dissolution process in $1: 1 \mathrm{ZnCl}_{2-}$ $\mathrm{ChCl} \mathrm{IL} \mathrm{at} 100{ }^{\circ} \mathrm{C}$ (ITO CE)

The possibility to dissolve $\mathrm{Pt}$ in $\mathrm{ZnCl}_{2}-\mathrm{ChCl}$ indicates that dissolution can be achieved in a type 1 eutectic-based IL, with the addition of a metal chloride. From the voltammograms measured for the 1:3 $\mathrm{ZnCl}_{2}$-EMIC (Figs. 1, 2) and the 1:1 $\mathrm{ZnCl}_{2}-\mathrm{ChCl}$ (Figs. 4, 5) it was concluded that the EW of the ILs needs to be at least $1.5 \mathrm{~V}$ in order to dissolve and deposit Pt. So the metal salt added needs to have a decomposition potential over $1.5 \mathrm{~V}$, in our case $\mathrm{ZnCl}_{2}$ or a less noble salt. As an alternative a Pt salt could be added directly to form an IL.

\section{Conclusions}

The electrochemical dissolution of Pt in several ILs has been studied. Different ILs were tested to assess their potential to dissolve Pt by evaluating their dissolution rate and current

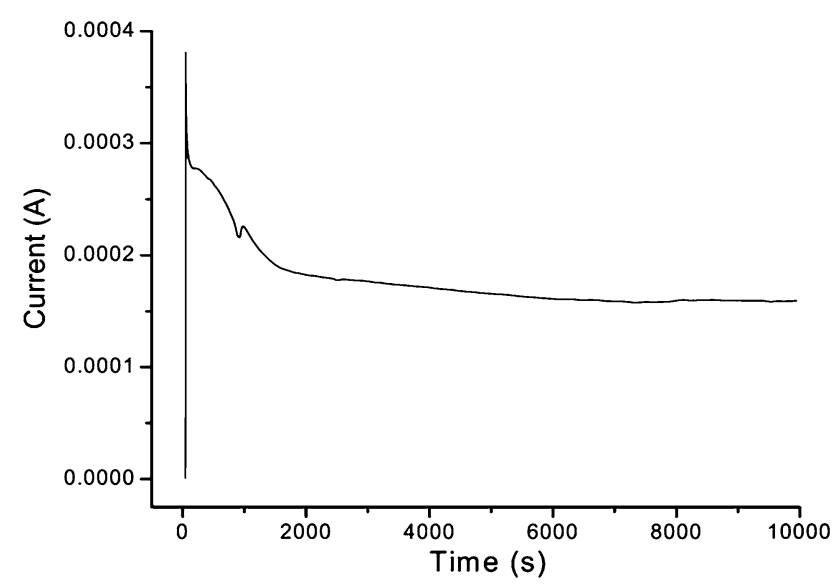

Fig. 7 Current/time transient from the chronoamperometric experiment at $\mathrm{E}=2.0 \mathrm{~V}$ for the $\mathrm{Pt}$ anodic dissolution process in $1: 1 \mathrm{ZnCl}_{2}-$ $\mathrm{ChCl} \mathrm{IL} \mathrm{at} 100{ }^{\circ} \mathrm{C}(\mathrm{Ti} \mathrm{CE})$

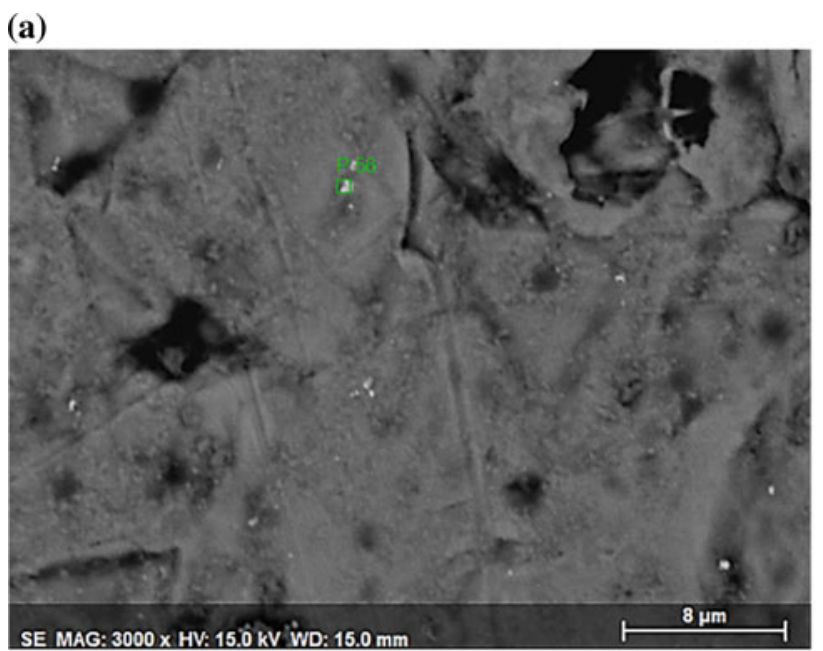

(b)

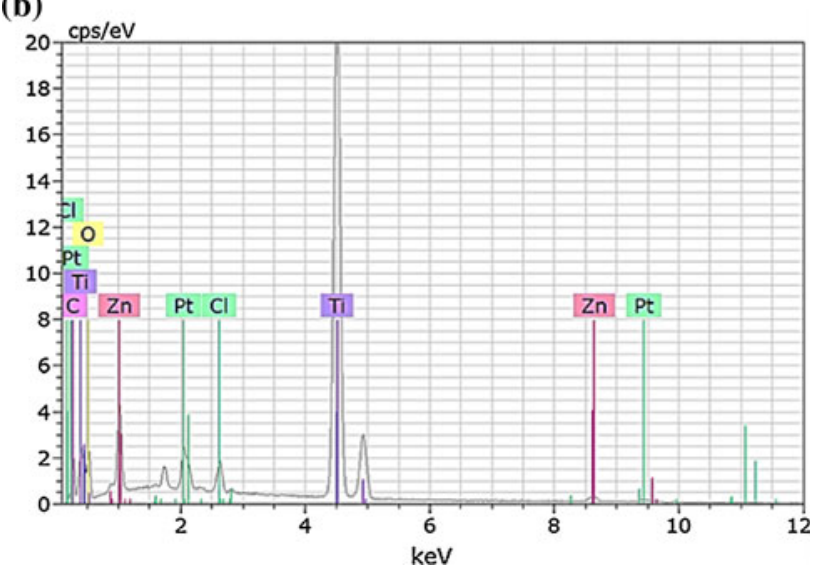

Fig. 8 Back scattered electron image (a) and corresponding EDS spectra (b) of the deposition on the Ti CE

efficiency. First the basic $1: 3 \mathrm{ZnCl}_{2}$-EMIC IL was reviewed. According to Huang and Chen [16] served as a solvent system for the electrodissolution of large amounts of Pt metal. 
The next objective was to find more industrial, less expensive systems that show at least the same result. The electrochemical behavior of the ILs was studied by voltammetry and chronoamperometry. The main focus was on $\mathrm{Cl}$ containing ILs of two generations: First generation, eutecticbased ILs and second generation ILs with discrete anions (e.g., EMIC). A further distinction was made between the different types of eutectic-based ILs: Type 1 metal salts (e.g., $\mathrm{ZnCl}_{2}$-choline chloride, $\mathrm{ZnCl}_{2}-\mathrm{ChCl}$ ), type 2 hydrated metal salts (e.g., $\mathrm{ZnCl}_{2} ; 2 \mathrm{H}_{2} \mathrm{O}-\mathrm{ChCl}$ ) and type 3 hydrogen bond donors (e.g., reline, ethaline).

$\mathrm{Pt}$ dissolution was only possible in type 1 eutectic-based ILs $\left(\mathrm{ZnCl}_{2}-\mathrm{EMIC}\right.$ and $\left.\mathrm{ZnCl}_{2}-\mathrm{ChCl}\right)$. These ILs contained $\mathrm{Cl}^{-}$anions in excess due to metal chloride salts added. At discrete potentials, these metal salts donated their $\mathrm{Cl}^{-}$ anions to the Pt metal. The Pt dissolved by forming a $\left[\mathrm{PtCl}_{\mathrm{x}}\right]^{\mathrm{y}-}$ complex in the electrolyte.

Comparing dissolution rates revealed that the dissolution of $\mathrm{Pt}$ in the $1: 3 \mathrm{ZnCl}_{2}-\mathrm{EMIC}$ IL is with $192.2 \mathrm{~g} \mathrm{~m}^{-2}$ $\mathrm{h}^{-1}\left(0.985 \mathrm{~mol} \mathrm{~m}^{-2} \mathrm{~h}^{-1}\right)$ significantly faster than in the 1:1 $\mathrm{ZnCl}_{2}-\mathrm{ChCl}$ IL with $9.090 \mathrm{~g} \mathrm{~m}^{-2} \mathrm{~h}^{-1}(0.0047 \mathrm{~mol}$ $\mathrm{m}^{-2} \mathrm{~h}^{-1}$ ). The price of EMIC being $€ 740 \mathrm{~kg}^{-1}$ higher than for $\mathrm{ChCl}$ makes it industrially less appealing. All other types of ILs tested did not show any Pt dissolution. This demonstrated that type 1 eutectic-based ILs can be successfully used when the EW of the ILs is at least $1.5 \mathrm{~V}$. The metal salt added should have a decomposition potential over $1.5 \mathrm{~V}$ : In our case $\mathrm{ZnCl}_{2}$ or a less noble salt.

Further investigations will be executed in type 1 ILs, focusing on the optimization of the $\mathrm{ZnCl}_{2}-\mathrm{ChCl}$ systems to improve the dissolution rate and the max. current density by addition of Pt salt, elevation of the temperature and stirring. It might also be interesting to investigate if a type 1 IL can be formed directly with a Pt salt.

Acknowledgments This research was supported by Umicore Group Research through a student internship. All analyses were performed by the analytical laboratory of Umicore Group Research.

\section{References}

1. Chen AC, Holt-Hindle P (2010) Chem Rev 110(6):3767-3804

2. Colón-Mercado R, Popov BN (2006) J Power Sources 155: 253-263
3. Demas JN, DeGraff BA (2001) Coord Chem Rev 211:317-351

4. Brabec V (2000) Electrochim Acta 45:2929-2932

5. Hagelüken C (2012) Platinum Met Rev 56(1):29-35

6. Butler J (2012) Platinum 2012. Johnson Matthey PLC, Hertfordshire

7. Kinnaird J (2011) Platinum Met Rev 55(2):117-123

8. Mudd GM (2012) Platinum Met Rev 56(1):2-19

9. Lin W, Zhang R-W, Jang S-S, Wong C-P, Hong JI (2010) Angew Chem 122:8101-8104

10. Lin W, Zhang R-W, Jang S-S, Wong C-P, Hong JI (2010) Angew Chem Int Ed 49:7929-7932

11. Barakat MA, Mahmoud MHH (2004) Hydrometallurgy 72(3-4):179-184

12. Kim M, Kim E, Jeong J, Lee J, Kim W (2010) Mater Trans 51(10):1927-1933

13. Kodera F, Kuwahara Y, Nakazawa A, Umeda M (2007) J Power Sources 172(2):698-703

14. Ohno H (2005) In: Ohno H (ed) Electrochemical aspects of ionic liquids. Wiley, Hoboken

15. Johnson KE (2007) Electrochem Soc Interface 16(1):38-41

16. Huang J-F, Chen H-Y (2012) Angew Chem Int Ed 51(7): $1684-1688$

17. O'Mahony AM, Silvester DS, Aldous L, Hardacre C, Compton RG (2008) J Chem Eng Data 53(12):2884-2891

18. Abott AP, Capper G, McKenzie KJ, Ryder KS (2007) J Electroanal Chem 599(2):288-294

19. Barron JC (2009) The electrochemistry of $\mathrm{Zn}$ in deep eutectic solvents. Doctoral thesis, University of Leicester, England

20. Alhaji A (2011) Electrodeposition of alloys from deep eutectic Solvents. Doctoral thesis, University of Leicester, England

21. The MEGlobal Group of Companies (2008) http://www.meglo bal.biz/media/product_guides/MEGlobal_MG.pdf. Accessed 16 July 2012

22. Hsiu SI, Huang JF, Sun IW, Yuan CH, Shiea J (2002) Electrochim Acta 47(27):4367-4372

23. Schubert T, Abedin SZE, Abbott AP, McKenzie KJ, Ryder KS, Enders F (2008) In: Endres F, MacFarlane D, Abbott AP (eds) Electrodeposition from ionic liquids. Wiley-VCH Verlag $\mathrm{GmbH}$ \& Co. KGaA, Weinheim, pp 83-123

24. Beyersdorff T, Schubert T, Welz-Biermann U, Pitner W, Abbott AP, McKenzie KJ, Ryder KS (2008) In: Endres F, MacFarlane D, Abbott AP (eds) Electrodeposition from ionic liquids. WileyVCH Verlag GmbH \& Co. KGaA, Weinheim, pp 15-46

25. Abbott AP, McKenzie KJ (2006) Phys Chem Chem Phys 8(37):4265-4279

26. Abbott AP, Capper G, Davies DL, Rasheed RK (2004) Chem Eur J 10(15):3769-3774

27. Anicai L, Florea A, Visan T (2011) In: Handy S (ed) Applications of ionic liquids in science and technology. InTech, Rijeka

28. Abbott AP, Capper G, Davies DL, Munro H, Rasheed RK, Tambyrajah V (2003) In: Rogers RD, Seddon KR (eds) Ionic liquids as green solvents. ASC, New York, pp 439-452 